\title{
ACCELERATION: THE (GOOD) USE OF THE MAGNIFYING GLASS
}

\author{
Oihane Iragüen Zabala \\ Universidad del País Vasco/Euskal Herriko Unibertsitatea, Dpto. Arte y Tecnología
}

\section{Abstract}

The studies of Science, Technology and Society, called STS studies, explore and determine the impacts of Science and Technology on social structure and its influences in the techno-scientific development. There are few approaches done from artistic disciplines. They question the link between Technology and Art, between Technics and values. They emphasize how currently in this dialectical relationship the humanist view remains in the background and the Technics overlay. From the Philosophy of Science several questions appear: if the Technology is a knowledge o just a tool to reach the knowledge, if Technology is a "know how" or a "know what". Nowadays we "know how" but we need to find out the "know what for".

\section{Keywords: SCIENCE; TECHNOLOGY; CYBERCULTURE; ACCELERATION; TECH- NICS}

\section{AZELERAZIOA: LUPAREN ERABILERA (EGOKIA)}

\section{Laburpena}

Zientzia, Teknologia eta Gizartea ikasketek, ZTG ikasketak deituak, zientzia eta teknologiaren eraginak aztertu eta zehazten dituzte gizarte egituran eta garapen teknozientifikoan. Ikasketa hauek diziplina ezberdinetatik teknokultura ikertzea dute helburu. Hurbilketa gutxi egin dira diziplina artistikoetatik. Hauek teknologia eta artearen lotura eztabaidatzen dute, teknika eta balioen artekoa. Dialektika honek bigarren mailan geratzeko daukan joera aztertzen dute, zernolako joera dagoen teknika gailentzean eta ikuspuntu humanista murriztean. Zientziaren Filosofía arloan gogoeta egiten dute: Teknologia ezagutza bat da edo ezagutzara ailegatzeko tresna soilik?, Teknologia "nola egiteko ezagutza" zehatza da edo "zer egiteko ezagutza"? Gaur egun, badakigu nola egin, baia zertarako egiten den ezagutzaren beharra nabarmentzen dute ikasketa hauek.

\section{Hitz gakoak: ZIENTZIA; TEKNOLOGIA; CIBERKULTURA; AZELERAZIOA; TEKNIKA}

\section{ACELERACIÓN: EL (BUEN) USO DE LA LUPA}

\section{Resumen}

Los estudios de Ciencia, Tecnología y Sociedad, llamados estudios CTS, exploran y determinan los impactos de la Ciencia y la Tecnología en la estructura social y las influencias en el desarrollo tecnocientífico. Estos estudios tratan de investigar la Tecnocultura desde diversas disciplinas. Existen escasas aproximaciones hechas desde las disciplinas artísticas. Éstas cuestionan el nexo entre la tecnología y el arte, entre la Técnica y los valores. Recalcan cómo actualmente en esta dialéctica queda en un segundo plano el enfoque humanista y se superpone la técnica. Desde la Filosofía de la tecnología se reflexiona si la Tecnología es un conocimiento o una herramienta para acceder a él, si la Tecnología es un "saber cómo" o un "saber qué". Hoy en día se "sabe cómo" pero se recalca la necesidad de cuestionar acerca del "saber para qué".

Palabras clave: CIENCIA; TECNOLOGÍA; CIBERCULTURA; ACELERACIÓN; TÉCNICA

Iragüen Zabala, Oihane. 2016. “Acceleration: The (good) use of the magnifying glass”. AusArt 4(1): pp-pp. 29-37 D0I: 10.1387/ausart.16674 


\section{INTRODUCTION OF SCIENCE, TECHNOLOGY ANS SOCIETY (STS) STUDIES}

When talking about techno-scientific culture and its impact in the contemporary culture is needed to talk about the STS studies. Studies of Science, Technology and Society, the goal of those studies is to investigate the interaction between science, technology and the impact that they have on society. STS studies were created almost 40 years ago, they form a multidisciplinary brunch from very different areas. The link between those STS researchers is to assert that Science, the Technology and the Society are closely related. Science and technology interact with most of the areas of society: politics, culture, and economy. Several studies add a negative view to the "progress" concept, however, they assert that they are the key for the understanding of contemporary society and its issue. They stress two main aspects in those interactions, on the one hand they explore the impacts of science and the technology in social structure, and on the other, they determine the measure in which all this would affect the technological development.

If culture is "information transmitted by social learning" (Mosterín, 1993, 111114 ) and this information is transmitted by verbal and non-verbal language, the consumption modes of those languages, the media, affects also for the apprehension of techno-culture. The Techno-culture term, or culture of technology, refers to the interactions between politics, technology and culture, and not just the interactions, but also to its impacts, constraints factors and its causes. Two basic features of techno-culture are: the speed and the ubiquity of production. To emphasise the rapidity of our current forms of connectivity Paul Virilio coined the term Dromology. Dromology is a concept to explain the acceleration of historic transformations and how new technologies are influencing society. Is a neologism for the new concept of time, virtuality, cyberspace and new ways of communication in digital era. These new modes of interaction have caused a big change in society, in personal relations, in memory and in the collective worldview.

\section{THE AGE OF ACCELERATION: INTERACTIVITY}

Virilio explained that exists three different dimensions to define each age: mass, energy and information. The mass, the citizens, is something precise 
and finite, where space-time where confrontation happens. The energy refers to the movement and dynamic in these happenings, where the limits little by little vanish away and space-time coordinates are becoming blurred. And finally, the third dimension:the information. Virilio stressed that this dimension is the one who defines different ages. Currently the information has a basic feature: the speed. For this author the speed is the contrary of time: the time has no speed, the time doesn't accelerate, the only thing that accelerates is the movement performed in time. Those movements have no time and no space because of the rapidity of their spread, and to refer to this ubiquity Virilio used the term: interactivity. From this term some concepts are created: reality, virtual reality, rupture in space-time perception, sense of orientation, etc. There are several theories about the time and the orientation on it, and this rupture and the spread of the space-time perception are the fault of speed (or interactivity). Those are the causes of the identity crisis in the age of cyber-culture. Virilio makes an historicfollow-up of social mutations and the impact of technology on them (virtual reality, electronic simulators, computerized systems).

Reinhart Koselleck explained years ago the spaces of experiences and the horizon of expectation. The experienced (lived) time and our position (decision-making) towards the future. From this dialectic struggle we configure and we anticipate the future.

Nowadays, the acceleration that Virilio spoke of prevents the communication between those two space/times. There are lots of studies about this acceleration: identity crisis, disturbance of perception, the destruction of the orientation-sense, the memory, etc. The time and the space are the raw material in the creation of memory, and currently they are not limited, because of the constant movements, its power of ubiquity, where different realities are built up (virtual reality, parallel reality, augmented reality, etc) and the resulting fault of orientation.

According to Virilio, through those technologies and through those massive mass media, is generating a new social look, or preferably, a training to create a new social look. In this construct the statics looses value and the dynamics wins, always on a constant flow. The new technologies of information create and produce contents, entertainment, symbolization, ultimately, they are in charge of producing a new way of "be and behave" in society where the real time lived creates a conflict: ¿how the real time is lived? Here there's a question about "what is real" and in which construct of reality are we living in. 


\section{THE SOCIETY THAT PULLS AND SOCIETY THAT PUSHES}

The consequences of the ICTs (Information and Communications Technology) and of the acceleration in the contemporary society are uncountable. The STS studies are trying to explore one by one the negative consequences of techno-scientific culture, at the expense of finding out solutions to solve the problems, not so many investigators support the rise of techno-scientific society. From philosophical currents, in particular from philosophy of science, to bring together positions, to try to place and to describe the present and the future of this technological societies (or cyber-societies), Science, Technology and Society mix up as a whole, and not for the purpose of establishing a hierarchy of the problems. From a holistic view, not with the aim of define exactly which are the causes and constraints of the use of technology.

The "society of information" and "society of knowledge" terms are born from Information and Communications Technology (ICT). Previously, before the emergence of "society of knowledge," the term used was "employer of knowledge", curiously nowadays in disused. "Society of information" and "society of knowledge", both concepts, refer to different things, after all the information is a tool to reach knowledge. "Society of information" is a society caused for ICT's, who bring real time information within reach. "Society of knowledge", to the contrary, is a society that appropriates, that re-interprets, this information with a specific purpose: a productive purpose. "The society of knowledge" has a variant: "society of understanding", the use of society of knowledge or of understanding has provoked several debates; neither the first nor the second are the same thing. The understanding (or knowing how) is related to technics, to the use oftechnological tools for example.

As Tomás Maldonado (Maldonado, 2007,226) stated: "The truth is that the matter of discussion is not so much recognising (or not) the importance of technicswhich is out of discussion- but rather establishing if we can assign (or not) a causal role to it taking into account the transformations in society". The cause of changes must be sought in within society and not in technics. It is a position that is summed up in this quote:

"The society is the cause; the technic is just the agent of the changes". (Maldonado, 2007, 226). 
According to defenders of technological determinism, the technic pushes and society pulls, and according the opponents, the other way round. On that point Maldonado made a reflection (he likened the process of technology to the biological parasitical process, more than a symbiosis) if it is a merely causality, stressing that in STS studies the circularity cannot be ignored.

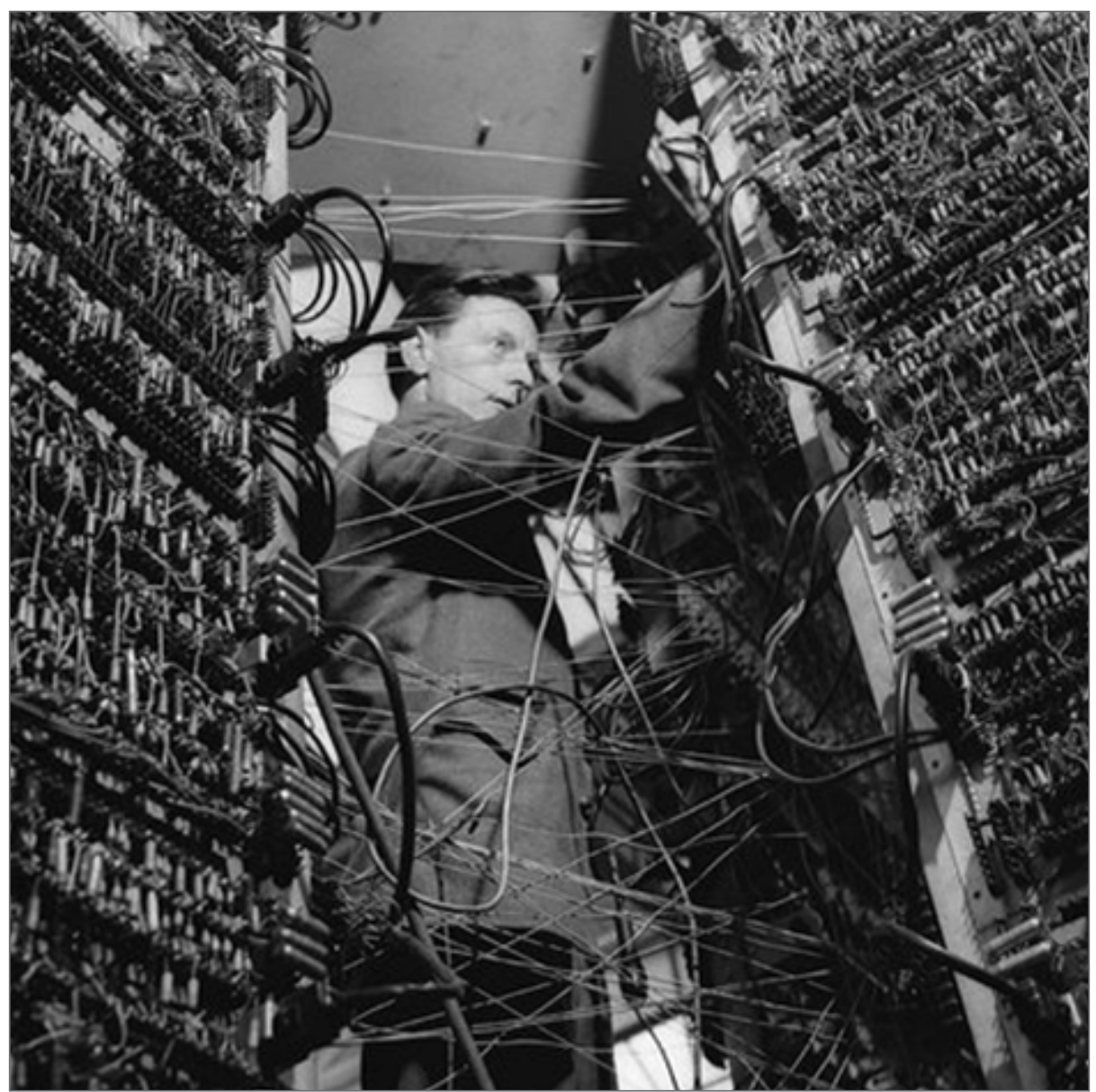

Source: http://elpais.com/diario/2011/06/18/babelia/1308355935 850215.html

In this case, if Science, Society and Technology are cause and effects at the same time, is they pull and push simultaneously, the 3 dimensions that Virilio highlighted, are not involved in this circularity too? 
If everything revolves around in circular movements of cause-effect and if this movement doesn't cease but accelerate, the question could be "where are we going?". If truly we can't see the future and this movement brought us the destruction of orientation in time, it may be possible to practice humanist initiatives from a critical and reflective posture. In this "identity crisis" caused (probably) by the bombardment of images where the society resides, where the "screen" changes the course of language, there's a possibility to make humanist initiatives/practices form techno-scientific practices.

\section{FROM “NO-PLACES" TO “GOOD TECHNOLOGICAL PLACES"}

When talking of cause-effect several dichotomies arise: knowledge-information, human-machine, experience-perception, written-language spoken-language, interface-user,... those dichotomies focus the debates of STS studies. The triumph of technics over values is proclaimed, a "know what for" over "know what". In fact, in philosophical currents, there's a problem to define technology, ¿is technology a knowledge? There are those who argue that technology is a tool created from science to achieve an end, is more a "know how" than a "know what", is an applied science. In the end a tool is not knowledge, but rather a lasting mark of it. The more external progress, the more internal regression. The more external order, the more internal chaos. In currently techno-scientific culture, is needed to distinguish between art and technic.

"The art is the part of technics that carries the hallmark of human personality on its fullest form and technics are the expression of art where a large portion of human personality is excluded with the aim of promote the mechanic process". (Mumford, 1895,256).

The more external progress, the more internal regression. Are the tools, the "know how", which determine different epochs, rather than "know what" or "know what for".

Maybe this process of the triumph of technics over the values, of the supremacy of "know how" over "know what for", probably comes from the first utopian constructions. Utopias have always been linked to human development, to the progress, to the use of social energies for the transformation of the society 
itself, to the same circularity of cause-effect. There are two types of utopias: utopias of escape and utopias of reconstruction. The first ones are not achievable, they try to escape from the world leaving it as it is, without altering it, and they are fictional. While the second one, tries to change it, interacting with society. Although Mumford explained that utopias of reconstruction couldn't exist without the escape ones.

Perhaps nowadays would be more complex the creation of new technologies, because we know how to create them but not what for. Tomás Moro created the concept Utopia, without knowing for sure if he created it to refer to eutopia (good place) or outopia (no-place). The Dromology could study future utopias (of reconstruction or not). Something clear is that everything is confused.

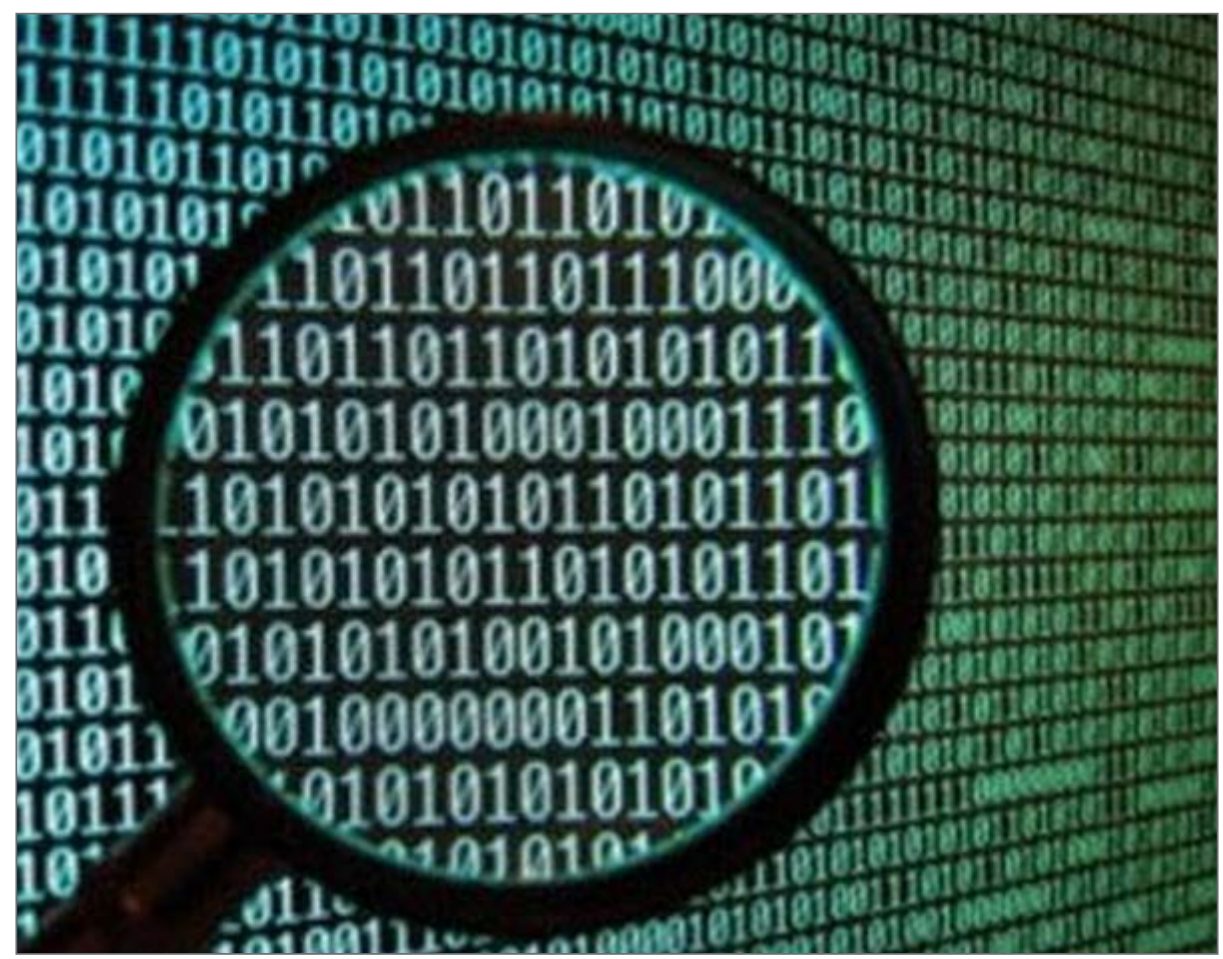

Source: http://previews.123rf.com/images/omnimages/omnimages1311/omnimages131100079/27182810-Lupa-sobre-la-huella-digital-de-unos-y-ceros-muestra-las-huellas-dactilares-naturales-Foto-de-archivo.jpg

We call to this era "society of knowledge", where the "know how" is placed in all areas of society, without the "know what". 
It is not always easy to separate the cause and the effect, and if both things are the same, if technology is a tool or knowledge, if society is cause and is the effect.

"To use a magnifying glass is to pay attention, but isn't paying attention already having a magnifying glass?"

(From Gaston Bachelard's Poetics of Space, 1969, 158)

To sum up, in the current confusion, it could be said that the use of the magnifying glass is just as significant as looking through it. It is necessary to place the magnifying glass on "what" do we want to change, on "what do we use for", although we all know how to make use of it. Actually the opulence of technics invite to chaos rather than to pay attention. Personally, making a reflection and trying to reinterpret the quote from Bachelard, this idea could be placed in the use of technology. We are users and participants of technology (of techno-culture), we have magnifying glasses, but we don't have our own discourse about the purpose of its use.

According to the third law of Arthur C. Clarke "Any sufficiently advanced technology is indistinguishable from magic", any technique attempts to emulate magic, and the more invisible it is, the more efficient it gets. There's magic on the screens, there's magic in communications, in art. According to Rodriguez-Ponga (https://elestadomental.com/radio/en-la-zona/pensamiento-magico), the role of the artist is a role of magical operator, the artist are "unravelers" of reality, they cope with the bond between reality and fantasy. Those operators are active as interpreters in communications between the intangible and tangible. In this articulation of fantasy, of technology, is where we should place the magnifying glass. Carlo Fabrettitried to continue with the Clarke's three laws: "People get used to what seems magic very easily, without worrying about understand how it works". The magnifying glass could be a determining factor for the "know how" and "know what for".

\section{References}

Aibar Puentes, Eduard \& Miguel Ángel Quintanilla Paz, eds. 2012. Ciencia, tecnología y sociedad. Madrid: Trotta

Alonso Puelles, Andoni \& Iñaki Arzoz Karasusan. 2003. Carta al "Homo ciberneticus": Un manual de ciencia, tecnología y sociedad activista para el siglo XXI. Madrid: Edaf

Bachelard, Gastón. (1957) 1969. La poétique de l'espace. París: PUF 
Clarke, Arthur C. (1962) 1973. Hazards of prophecy: The failure of imagination". London: Pan Books

Gómez Vargas, Héctor. 1999. "Cuando la aceleración y la realidad virtual nos alcancen". Reseña de "El arte del motor" de Paul Virilio. Estudios sobre las Culturas Contemporáneas $\mathrm{V}(9), 167-70$

Koselleck, Reinhart. (1979) 1993. Futuro pasado: Para una semántica de los tiempos históricos. Traducción de Norberto Smilg. Barcelona: Paidós

Maldonado, Tomás. 2007. Memoria y conocimiento : Sobre los destinos del saber en la perspectiva digital. Traducción de Flavia Costa y Teresa D'Meza. Barcelona: Gedisa

Martínez Reinoso, Rodrigo Guillermo. 2013. "Reseña Lewis Mumford: El pentágono del poder-El mito de la máquina (Volumen II)". Oxímora Revista Internacional de Ética y Política 3 (otoño), 135-9

Mitcham, Carl, 1989. ¿Qué es la filosofía de la tecnología? Traducción de César Cuello Nieto y Roberto Méndez Stingl. Madrid: Anthropos

Mosterín, Jesús. 1993. Filosofía de la cultura. Madrid: Alianza

Mumford, Lewis. (1922) 2013. Historia de las utopías. Traducción, Diego Luis Sanromán Peña. Logroño: Pepitas de Calabaza

- (1970) 2011. El mito de la máquina, Tomo II: El pentágono del poder. Traducción: Javier Rodríguez Hidalgo. Logroño: Pepitas de Calabaza

- (1973) 2016. Ensayos: Interpretaciones y pronósticos (1922-1972). Traducción, Diego Luis Sanromán Peña. Logroño: Pepitas de Calabaza

Pardo Torío, Jose Luis. 2011. "La vida y la máquina” El País-Babelia, 16 junio. http://elpais.com/ diario/2011/06/18/babelia/1308355935 850215.html

Ricoeur, Paul (1978), 1999. "Filosofía y lenguaje". En Historia y narratividad, traducción, Gabriel Aranzueque Sahuquillo, 41-58. Barcelona: Paidós

Rodriguez-Ponga, Claudia. 2016. "El hotel eléctrico: O del 'luxo' al 'lixo' en un abracadabra”. El Estado Mental, 6 abril. https://elestadomental.com/diario/el-hotel-electrico

- 2016. "Pensamiento mágico". Conversación con Bruno Galindo. El Estado Mental-EEM Radio, programa En la zona. Podcast de radio, 59:38, 8 mayo. https://elestadomental.com/ radio/en-la-zona/pensamiento-magico

Yehya, Naief. 2001. El cuerpo transformado. Cyborgs y nuestra descendencia tecnológica. México DF: Paidós

Virilio, Paul. 1980. Esthétique de la disparition. París: André Balland

- 1993. L'art du moteur. Paris: Galilée

Zafra Alcaraz, Remedios. 2010. Un cuarto propio conectado: (Cyber) espacio y (auto)gestión del Yo. Madrid: Fórcola

(Artículo recibido 25.04.16; aceptado 19.05.16) 